\title{
Effect of Acidic Environment on the Surface Microhardness of Biodentine ${ }^{\mathrm{TM}}$
}

\author{
Gaurav Poplai, Sameer K Jadhav, Vivek Hegde
}

\begin{abstract}
Aim: To compare the effects of various levels of acidic $\mathrm{pH}$ on surface microhardness of Biodentine. ${ }^{\mathrm{TM}}$
\end{abstract}

Materials and methods: Biodentine was mixed and packed into stainless steel molds (diameter $=5 \mathrm{~mm}$ and height $=$ $1.5 \mathrm{~mm}$ ). Four groups of 10 specimens each were formed and exposed to $\mathrm{pH}$ : 7.4, 6.4, 5.4 and 4.4 respectively for 4 days. Vickers microhardness was measured for each of the specimens and was measured 4 days after the exposure.

Results: Data was subjected to one-way ANOVA using Tukey's post hoc test. Group I (control pH = 7.4) showed greatest surface microhardness of $67.5 \pm 4.1 \mathrm{HV}$. The least microhardness of $46.3 \pm 5.0 \mathrm{HV}$ was observed for group IV where the specimens were soaked at $\mathrm{pH}$ 4.4. A p-value less than 0.05 was considered to be statistically significant.

Conclusion: Under the limitations of the present study, surface hardness of Biodentine was impaired in the presence of acidic environment.

Keywords: Biodentine, Mineral trioxide aggregate, Microhardness.

How to cite this article: Poplai G, Jadhav SK, Hegde V. Effect of Acidic Environment on the Surface Microhardness of Biodentine $^{\mathrm{TM}}$. World J Dent 2013;4(2):100-102.

Source of support: Nil

Conflict of interest: None declared

\section{INTRODUCTION}

Mineral trioxide aggregate has been used for repair of root perforations, root end filling material, vital pulp therapy including direct pulp capping and pulpotomy of immature teeth with vital pulps (apexogenesis) and as an apical barrier for teeth with open apices ${ }^{1-4}$ making it an extremely popular endodontic material, but the search for better endodontic materials has lead to the introduction of a tricalcium silicatebased material called Biodentine ${ }^{\mathrm{TM}}$, which has clinical applications similar to those of MTA. ${ }^{5}$

Variations in the periapical $\mathrm{pH}$ can affect the physical and chemical properties of a root end filling material. The effect of acidic $\mathrm{pH}$ on the surface microhardness of MTA has been well documented. ${ }^{6}$ As sufficient literature on Biodentine is lacking, the present study was designed to evaluate the surface microhardness of the material when exposed to different levels of acidic $\mathrm{pH}$.

\section{MATERIALS AND METHODS}

Biodentine was mixed in an amalgamator according to manufacturer's instructions. Forty specimens were prepared by packing the material in customized stainless steel molds (diameter $=5 \mathrm{~mm}$ and height $=1.5 \mathrm{~mm}$ ) using a nonsurgical manual MTA carrier (Dentsply, Tulsa Dental) and manual pressure. ${ }^{7}$ Specimens were then divided into four groups of 10 specimens each. Each group was placed in a separate vial. In group I, the bottom of the vial contained a piece of $2 \times 2 \mathrm{~cm}$ gauze that had been soaked in phosphate-buffered saline solution ( $\mathrm{pH}=7.4$ ). In groups II, III and IV the bottom of the vial contained a piece of $2 \times 2 \mathrm{~cm}$ gauze that had been soaked in butyric acid buffered at $\mathrm{pH}$ values of 6.4, 5.4 and 4.4 respectively. Acid-soaked pieces of gauze were replaced every day with fresh ones to ensure sufficient acidic environment within the vials. The specimens were then incubated for 4 days at $37^{\circ} \mathrm{C}$.

After 4 days all the specimens were removed from the different $\mathrm{pH}$ solutions; they were washed and gently dried with air spray. The specimens were polished by using minimum hand pressure and silicon carbide based 1,000-grit particle size sandpaper. The Vickers microhardness test was performed by using microhardness tester (Shimadzu HMV 2000; Vickers pyramid indenter shape, Kyoto, Japan) with square-based pyramid-shaped diamond indenter with angle of 136 between the opposite faces. A full load of $50 \mathrm{gm}$ was applied for 10 seconds at room temperature. The Vickers microhardness of each specimen was calculated by measuring the diagonal diameter of the resulting indentation. Four indentations were produced on the surface of each specimen. A blinded operator used the mean hardness of each indentation to calculate the differences among the groups. The Vickers microhardness is calculated using the following formula: $\mathrm{HV}=1.854$ $\left(\mathrm{F} / \mathrm{d}^{2}\right)$ approximately where $\mathrm{F}=\mathrm{load} / \mathrm{kg}$ and $\mathrm{d}=$ the mean of the two diagonals of the impression made by the indenter in millimeters.

\section{RESULTS}

The data obtained after the surface microhardness test was performed is tabulated in Table 1 . The mean retentive strength of the test groups are shown in Graph 1 and the statistical comparison of groups are shown in Table 2. The data was analyzed by one-way analysis of variance (ANOVA) using Tukey's post hoc correction for multiple group comparisons. The greatest mean surface hardness values were shown by group I (control $\mathrm{pH}=7.4$ ) which 


\begin{tabular}{ccccc}
\hline \multicolumn{5}{c}{ Table 1: Microhardness (in HV) } \\
\hline $\begin{array}{c}\text { Sample } \\
\text { ID }\end{array}$ & $\begin{array}{l}\text { Group I } \\
\text { (control) }\end{array}$ & $\begin{array}{l}\text { Group II } \\
\text { (pH 6.4) }\end{array}$ & $\begin{array}{l}\text { Group III } \\
\text { (pH 5.4) }\end{array}$ & $\begin{array}{l}\text { Group IV } \\
(\text { pH 4.4) }\end{array}$ \\
\hline 1 & 70.23 & 70.23 & 55.43 & 43.62 \\
2 & 65.28 & 64.45 & 58.96 & 38.85 \\
3 & 62.77 & 66.53 & 68.55 & 52.93 \\
4 & 72.40 & 61.76 & 65.40 & 45.58 \\
5 & 61.82 & 61.28 & 59.23 & 48.35 \\
6 & 72.32 & 68.56 & 59.45 & 47.88 \\
7 & 71.45 & 62.40 & 66.71 & 54.14 \\
8 & 68.49 & 63.47 & 67.32 & 45.49 \\
9 & 63.87 & 69.14 & 61.27 & 39.32 \\
10 & 66.11 & 70.64 & 56.64 & 46.67 \\
\hline
\end{tabular}

Table 2: Statistical comparison of groups

\begin{tabular}{ll}
\hline Group comparison & Microhardness \\
\hline Group I vs group II & 0.823 \\
Group I vs group III & 0.032 (significant) \\
Group I vs group IV & 0.001 (significant) \\
Group II vs group III & 0.203 \\
Group II vs group IV & 0.001 (significant) \\
Group III vs group IV & 0.001 (significant) \\
\hline
\end{tabular}

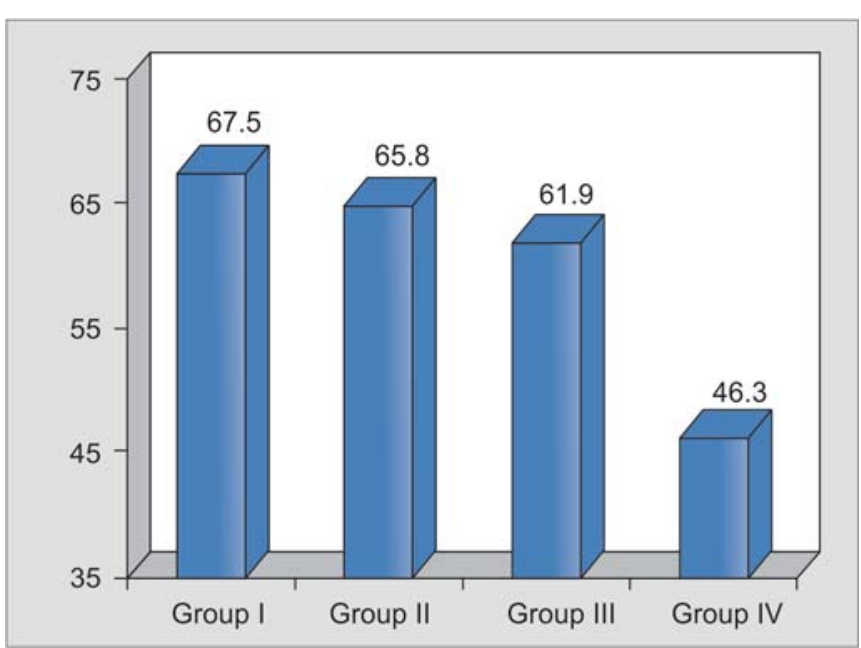

Graph 1: Mean microhardness of each group (in HV)

showed mean microhardness of $67.5 \pm 4.1 \mathrm{HV}$ with the values decreasing to $46.3 \pm 5.0 \mathrm{HV}$ for specimens of group IV $(\mathrm{pH}=4.4)$. Group II $(\mathrm{pH}=6.4)$ showed mean microhardness of $65.8 \pm 3.6 \mathrm{HV}$ which was not statistically significant when compared to group I. Group III $(\mathrm{pH}=5.4)$ showed mean microhardness of $61.9 \pm 4.7 \mathrm{HV}$. The p-value less than 0.05 was considered to be statistically significant.

\section{DISCUSSION}

A root-end filling material is invariably placed in an environment where inflammation is present and where the $\mathrm{pH}$ is likely to be acidic. ${ }^{8,9}$ This acidic $\mathrm{pH}$ is likely to be an impediment to the setting reaction of Biodentine causing it to affect the microhardness of the set material.

Hardness as defined by O'Brien ${ }^{10}$ is the resistance of material to indentation, and it correlates to material's strength and rigidity. ${ }^{11}$ The microhardness of a material is not a measure of a single property. It is influenced substantially by other fundamental properties of the material such as yield strength, tensile strength, modulus of elasticity and crystal structure stability. ${ }^{12}$ Thus when compared with baseline information; it can be used as an indicator of the setting process and the overall strength or resistance to deformation.

Danesh et $\mathrm{al}^{13}$ reported the Vickers microhardness of MTA to be 39.99. Namazikhah et $\mathrm{al}^{6}$ noted that at a $\mathrm{pH}$ of 7.4 the Vickers microhardness of MTA was 53.19 which reduced drastically as the $\mathrm{pH}$ was lowered.

The present study which was designed to evaluate the surface microhardness of Biodentine as an indicator of the setting process following exposure to a range of acidic $\mathrm{pH}$ during hydration showed that the surface microhardness of Biodentine at $\mathrm{pH} 7.4$ was $67.5 \pm 4.1 \mathrm{HV}$. And even at $\mathrm{pH}$ as low as 4.4 the surface microhardness was $46.3 \pm 5.0 \mathrm{HV}$. Biodentine showed higher values of microhardness when compared to the microhardness tests carried out on MTA in previous studies.

Higher values of microhardness of Biodentine can be explained on the basis of calcium chloride present in the liquid provided by the manufacturer. The addition of $\mathrm{CaCl}_{2}$ is intended to reduce the setting time of the Portland cement and to improve its physicochemical properties in civil construction. ${ }^{14,15}$

A possible explanation behind calcium chloride enhancing the physical properties are that calcium chloride penetrates the pores of cements, strongly accelerating the hydration of silicates and leading to their faster crystallization and reducing the setting time. ${ }^{16,17}$

\section{CONCLUSION}

Acidic environment significantly reduces the surface microhardness of Biodentine, but when compared to the microhardness values of MTA garnered in previous studies, Biodentine showed higher surface hardness.

\section{ACKNOWLEDGMENTS}

The authors wish to thank Mr Bhagat at Praj Metallurgical Laboratory, Pune, Maharashtra for his assistance with microhardness testing.

\section{Manufacturer Names}

a. Biodentine (Septodont)

b. Carrier used for Biodentine-MTA carrier (Dentsply, Tulsa Dental)

c. Microhardness tester (Shimadzu HMV 2000, Kyoto, Japan). 


\section{REFERENCES}

1. Lee SJ, Monsef M, Torabinejad M. Sealing ability of a mineral trioxide aggregate for repair of lateral root perforations. J Endod 1993;19:541-44.

2. Torabinejad M, Watson TF, Pitt Ford TR. Sealing ability of a mineral trioxide aggregate when used as a root-end filling material. J Endod 1993;19:591-95.

3. Torabinejad M, Chivian N. Clinical applications of mineral trioxide aggregate. J Endod 1999;25:197-205.

4. Shabahag S, Torabinejad M. Treatment of teeth with open apices using mineral trioxide aggregate. Pract Pedodontics and Aesthet Dent 2000;12:315-20.

5. Septodont RD. Department Biodentine ${ }^{\mathrm{TM}}$-Active Biosilicate Technology Scientific File, 2009.

6. Namazikhah MS, Nekoofar MH, Sheykhrezae MS, et al. The effect of $\mathrm{pH}$ on surface hardness and microstructure of mineral trioxide aggregate. Int Endod J 2008;41:108-16.

7. Aminoshariae A, Hartwell GR, Moon PC. Placement of mineral trioxide aggregate using two different techniques. J Endod 2003;29:679-82.

8. Malmed SF. Handbook of local anaesthesia (5th ed). St Louis Mosby: Elsevier 2004:43-44.

9. Nekoofar MH, Namazikhah MS, Sheykhrezae MS, et al. pH of pus collected from periapical abscesses. Int Endod J 2009;42:534-38.

10. Anusavice KL. Mechanical properties of dental materials in Philip's science of dental materials (10th ed). Philadelphia: WB Saunders Co 1996:69.

11. O'Brien WJ. Physical properties in dental materials and their selection (3rd ed). Illinois: Quintessence Publishing Co; 1997:18.

12. Blake A. Handbook of mechanics, materials and structures (1st ed). New York: Wiley-IEEE 1985:25-28.

13. Danesh G, Dammaschke T, Gerth HU, et al. A comparative study of selected properties of ProRoot mineral trioxide aggregate and two port land cements. Int Endod J 2006;39: 213-19.

14. Technical handbook: Additives for concrete and mortars (39th ed). Salvador: Vedacit 2003 [In Portuguese].

15. Aquilina JW. The physical properties of accelerated Portland cement. University of London, Project Report 1999.

16. Ramachandran VS. Concrete admixtures handbook. New Jersey: Noyes Publications 1984;187-210.

17. Popovics S. Concrete making. McGraw-Hill Book Company: Washington 1979.

\section{ABOUT THE AUTHORS}

\section{Gaurav Poplai}

Student, Department of Conservative Dentistry and Endodontics, MA Rangoonwala College of Dental Sciences and Research Centre, Pune Maharashtra, India

Correspondence Address: B-44 Cozi Hom, 251 Pali Hill, Mumbai400050 Maharashtra, India, Phone: 9096666367, e-mail: gpoplai@ hotmail.com,gpoplai@gmail.com

\section{Sameer K Jadhav}

Professor, Department of Conservative Dentistry and Endodontics MA Rangoonwala College of Dental Sciences and Research Centre Pune, Maharashtra, India

\section{Vivek Hegde}

Professor and Head, Department of Conservative Dentistry and Endodontics, MA Rangoonwala College of Dental Sciences and Research Centre, Pune, Maharashtra, India 